\title{
Completing the puzzle: Another species of Rhaucus Simon, 1879 (Arachnida: Opiliones: Cosmetidae) from Colombia
}

\author{
Andrés F. García ${ }^{1, *}$, Daniela Ahumada-C. ${ }^{2}$ \\ ${ }^{1}$ Departamento de Invertebrados, Museu Nacional/UFRJ, Rio de Janeiro, Brasil \\ ${ }^{2}$ Grupo de Investigación en Biología Descriptiva y Aplicada, Grupo de Investigación en Hidrobiología, \\ Programa de Biología, Universidad de Cartagena, Cartagena de Indias, Colombia
}

\begin{abstract}
Rhaucus papilionaceus (Simon, 1879) restored combination is revalidated, as previously stated by Henriksen (1932). A redescription of the species including Scanning Electron Microscopy (SEM) images and a distribution map is offered. This species represents the sixth valid species of the genus and extends its altitudinal range to lowest forests in the Colombian Andes (1500 m a.s.1.). (C) 2018. Acad. Colomb. Cienc. Ex. Fis. Nat.

Key words: Laniatores; Colombia; Taxonomy; Andes; Diversity.

Se completa el rompecabezas: otra especie de Rhaucus Simon, 1879 (Arachnida: Opiliones: Cosmetidae) de Colombia

\section{Resumen}

Se revalidó la combinación restaurada de Rhaucus papilionaceus (Simon, 1879) según lo indicado previamente por Henriksen (1932). Se ofrece una nueva descripción de la especie, incluidas imágenes tomadas con microscopio electrónico de barrido (Scanning Electron Microscopy, SEM) y un mapa de distribución. Esta especie representa la sexta especie válida del género y extiende su rango altitudinal a los bosques bajos en los Andes colombianos (1.500 m.s.n.m.). (C) 2018. Acad. Colomb. Cienc. Ex. Fis. Nat.
\end{abstract}

Palabras clave: Laniatores; Colombia; Taxonomía; Andes; Diversidad.

\section{Introduction}

The Neotropical harvestmen family Cosmetidae C.L. Koch, 1839 is the second most diverse among the suborder Laniatores, with 126 genera and 719 species (Kury, 2003; 2013; Kury \& Barros, 2014; Kury \& García, 2016). Rhaucus Simon, 1879 is a harvestman genus that occurs in the Andean region of Colombia, especially in montane forests and páramos from Santander, Boyacá, and Cundinamarca departments (García \& Kury, 2017).

Currently, this genus contains five species: Rhaucus florezi García \& Kury, 2017; Rhaucus quinquelineatus Simon, 1879; Rhaucus robustus (Mello-Leitão, 1941); Rhaucus serripes (Simon, 1879), and Rhaucus vulneratus Simon, 1879 (type species) (García \& Kury, 2017).

However, in a revision of harvestmen material from Colombia, we identified some specimens of Erginus papilionaceus Simon 1879, currently Flirtea papilionacea (Simon, 1879) (Kury, 2003) that match the diagnosis of Rhaucus given by García \& Kury (2017). Thus, in this work we redescribed the species and propose the combination Rhaucus papilionaceus (Simon, 1879) restored combination, a combination previously stated by Henriksen (1932). Additionally, a map with the known records in Colombia is given.

\section{Materials and methods}

We photographed specimens using a Sony Cybershot DSC-V1 camera. We integrated the multiple resultant images at different focal planes with the Combinezp Suite software (Hadley, 2015). To increase the depth of field, integrated images were then edited with the Photoshop ${ }^{\circledR}$ CC 2014 software. Drawings of the species were made using Inkscape 0.91 software.

For color descriptions, we used the standard names of the 267 Color Centroids of the NBS/IBCC Color System (http://people.csail.mit.edu/jaffer/Color/Dictionaries\#nbsiscc) (Jaffer, 2001) as explained in Kury (2012). Scanning Electron Microscopy (SEM) was carried out with a JEOL JSM-6390LV microscope at the Center for Scanning Electron Microscopy of the Museu Nacional/UFRJ with an accelerating voltage of $10 \mathrm{kV}$ after sputter-coating with gold-palladium.

*Corresponding autor:

Andrés F. García, agarciarinc@gmail.com

Received: January 27, 2018

Accepted: April 19, 2018

Editor: Marta Ramírez Pinilla 
Geographic coordinates have been transcribed verbatim from the labels and maybe in different formats; when there was no indication of coordinates, these were interpolated between square brackets using Google Maps to indicate that they were estimates. The distribution map was made using SimpleMappr (Shorthouse, 2010). Colored shapes make reference to WWF world ecoregions (Olson, et al., 2001).

The morphological terminology follows: Kury \& Barros (2014), Kury \& Medrano (2016) and García \& Kury (2017) for dorsal scutum, coda, clavi inguines and other anatomic terms; Kury \& Villarreal (2015), Medrano \& Kury (2016) and Kury (2016) for macrosetae and microsetae of male genitalia. The stylus in Cosmetidae has a serrate fleshy caruncle (Kury \& Ferreira, 2012), called a "wattle" (Kury \& Barros, 2014; Kury \& Villarreal, 2015).

The morphometric abbreviations are the following: $\mathrm{AL}=$ maximum abdominal scutum length, AW = maximum abdominal scutum width, $\mathrm{BaCh}=$ basichelicerite length, $\mathrm{ci}=$ clavi inguines, $\mathrm{CL}=$ carapace length, $\mathrm{CW}=$ carapace width; $\mathrm{DS}$ $=$ dorsal scutum, $\mathrm{Fe}=$ femur, $\mathrm{mca}=$ multicapitate apophysis, $\mathrm{MS}=$ macrosetae of penis, $\mathrm{Pa}=$ patella, $\mathrm{Ti}=$ tibia, $\mathrm{VP}=$ ventral plate. All measurements are in mm unless otherwise noted. The following are the abbreviations of the repositories: ICN-AO (Instituto de Ciencias Naturales - Arachnida Opiliones, Bogotá, Colombia: curator Eduardo Flórez) and MNRJ (Museu Nacional, Universidade Federal do Rio de Janeiro, Rio de Janeiro, Brazil: curator Adriano Kury).

\section{Results}

Rhaucus papilionaceus. (Simon, 1879) restored combination. (Figures 1-8).

Flirtea papilionacea (Simon, 1879)

- Erginus papilionaceus Simon 1879: 205

Flirtea papilionacea: Roewer 1912: 77; Roewer 1923: 347; Roewer 1927: 593; Mello-Leitão 1932: 78; Kury 2003: 62

Rhaucus (Erginus) papilionaceus: Henriksen 1932: 352.

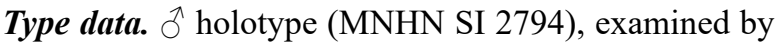
photograph (Figure 1).

Material examined. COLOMBIA, Boyacá department: (ICN-AO-63) 1 ㅇ from [Moniquirá], Togüi, finca de Pedro Ruíz, [5.936392, -73.514004], ii.1978, 1650 m, I. de Arevalo leg.; Santander department: (ICN-AO-441) 1 우 from Suaita, San José de Suaita, vereda Neftalí, [6¹0’3.60”N 7326'44.00"W], 1550 m, 5.x.1998, animal systematics students leg.; (ICN-AO-768) 1 $\sigma^{\Uparrow}$ from Zapatoca, [6 ${ }^{\circ} 49^{\prime} 4.28^{\prime \prime}$ N 73¹6’36.93" W], v.2008, cave, Solimary García leg.; (ICN-AO-877) 10 from Puente Nacional, Finca El Mirador, 5.90282N -73.694950W,13.vi.2011, 1720 m, Lina Escobar leg.; (ICN-AO-1053) 1 f from Zapatoca, quebrada Uchubala, 6 6 48’34.40”N; 73¹5'54,70”W, 31.v.2012, J. Díaz leg.; (ICN-AO-1089) 1 ㅇ from Charalá, Virolín, Cuchilla del Fara, 06 5'47.4" N 73¹3'00.7" W, vi.2012, $1718 \mathrm{~m}$, L. Escobar leg.; (ICN-AO-1162) $3 \overbrace{}^{\lambda}$ from San Gil, Vereda Resumidero, road to Mogotes, $06^{\circ} 32$ '28.25” N 735'28.75”

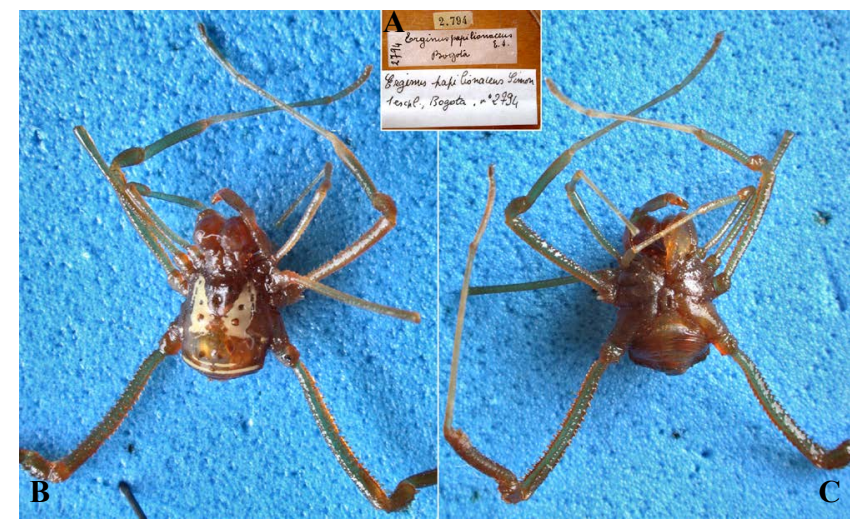

Figure 1. Type material of Erginus papilionaceus Simon, 1879 (MNHN SI 2794). A. Original labels. B. Male holotype, dorsal view. C. Same, ventral view. Photographs courtesy of Ricardo Pinto-da-Rocha.

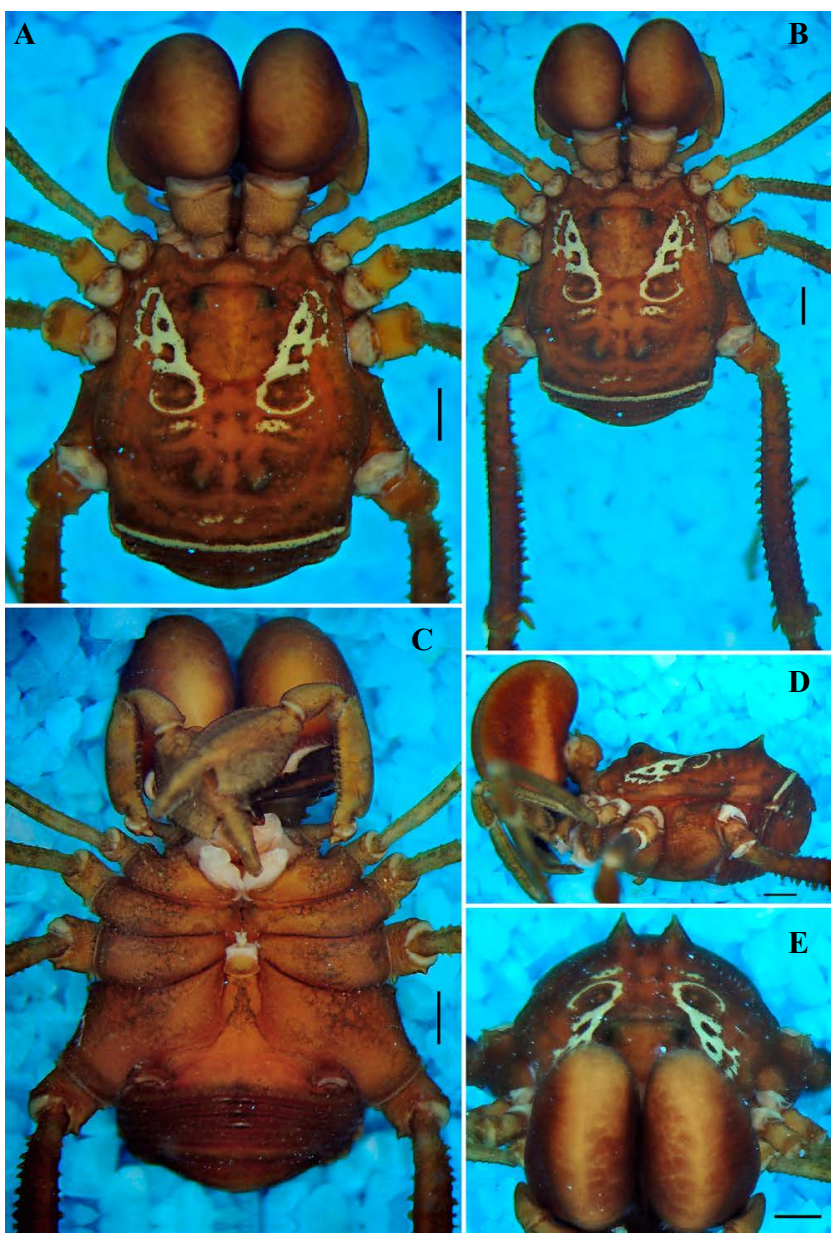

Figure 2. Rhaucus papilionaceus rest. comb. (ICN-AO-1162), male habitus: A. Dorsal view. B. Panoramic view. C. Ventral view. D. Lateral view. E. Frontal view. Scale bars $=1 \mathrm{~mm}$.

W, 1600 m, 30.iii.2013, under log, A. García leg.; (MNRJ 2676) 10 , same data as ICN-AO-1162; (ICN-AO-1215) 1 q from road Piedecuesta-Sevilla [vereda Sevilla] [6.981232, 


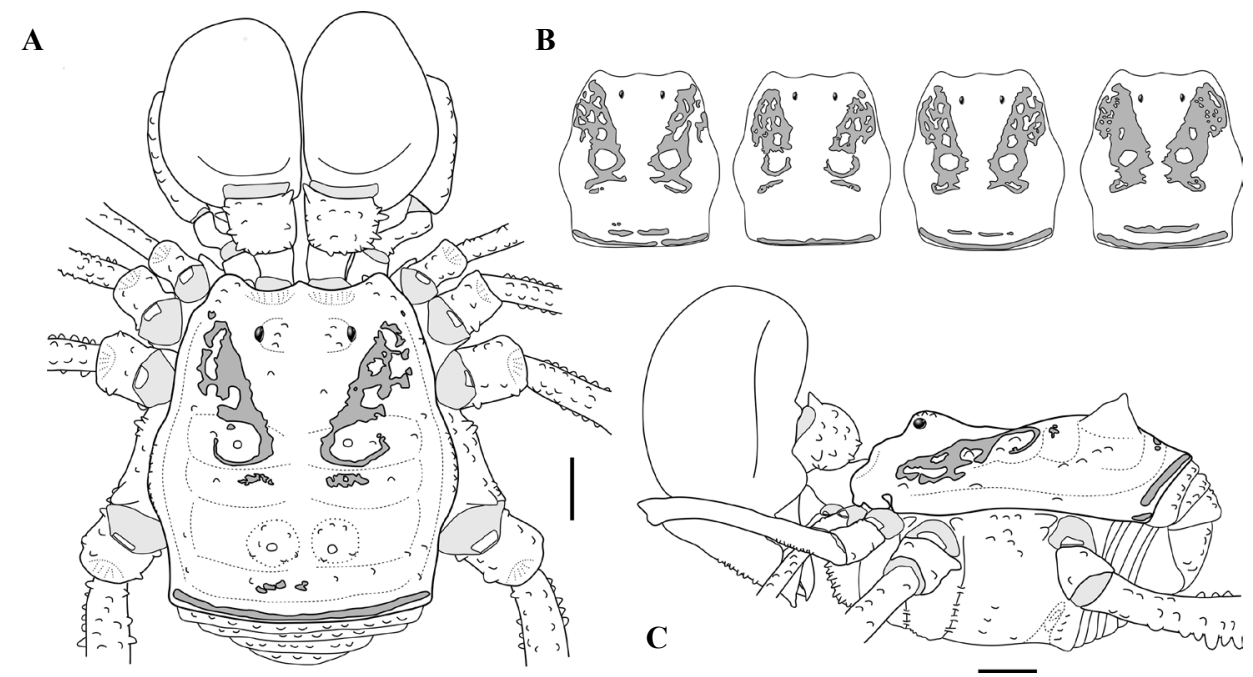

Figure 3. Rhaucus papilionaceus rest. comb. (ICN-AO-1162) A. Dorsal view. B. Variations of dorsal scutum blots. C. Lateral view. Scale bars $=1 \mathrm{~mm}$.

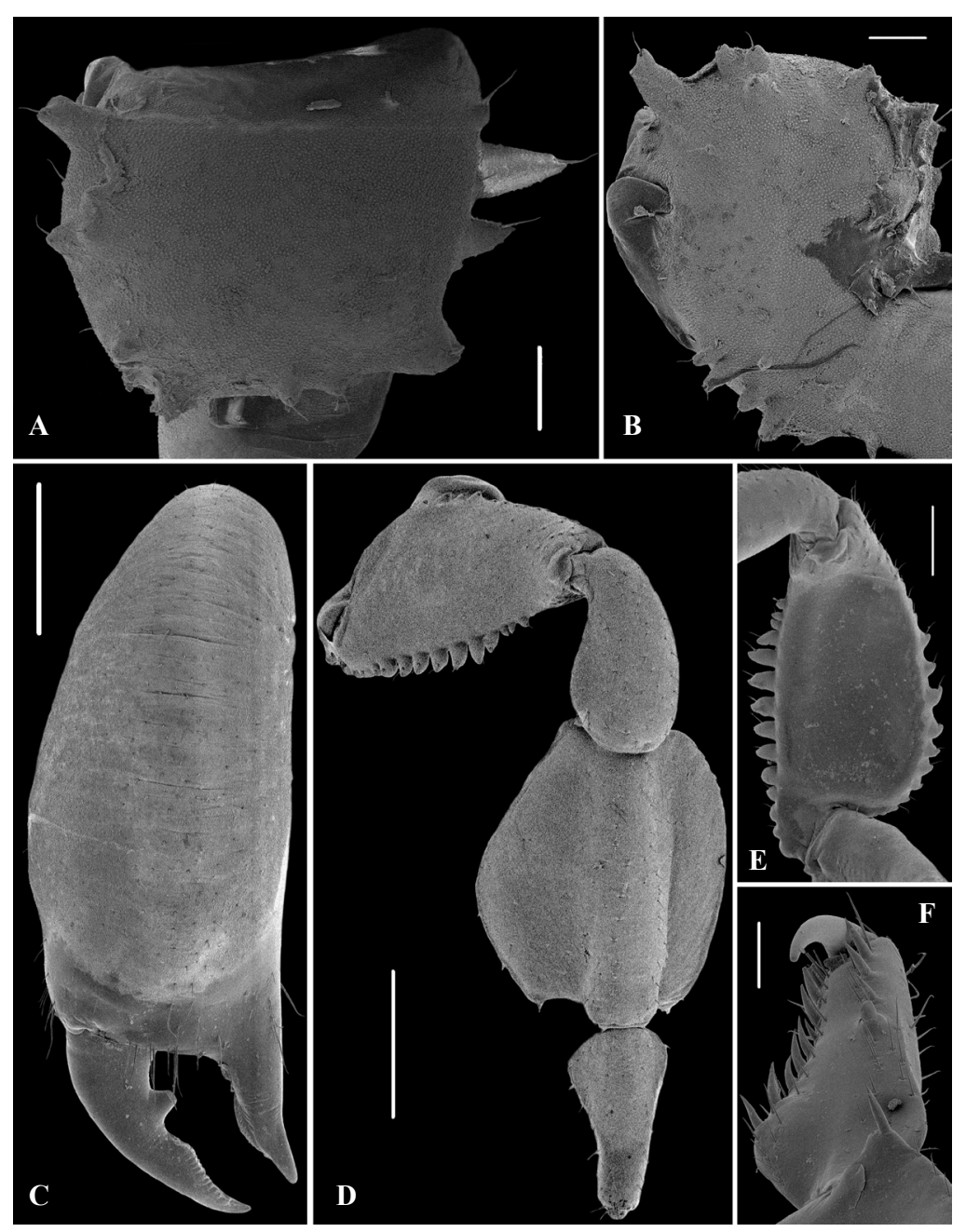

Figure 4. SEM images of Rhaucus papilionaceus rest. comb. (ICN-AO-1162), male: Chelicera (A-C): A. Basichelicerite, dorsal view. B. Same, mesal view. C. Hand, frontal view. Pedipalp (D-F): D. Frontal view. E. Femur, mesal view. F. Tarsus, mesal view. Scale bars: A-B, $\mathrm{F}=200 \mu \mathrm{m} ; \mathrm{C}-\mathrm{D}=1 \mathrm{~mm}, \mathrm{E}=500 \mu \mathrm{m}$. 

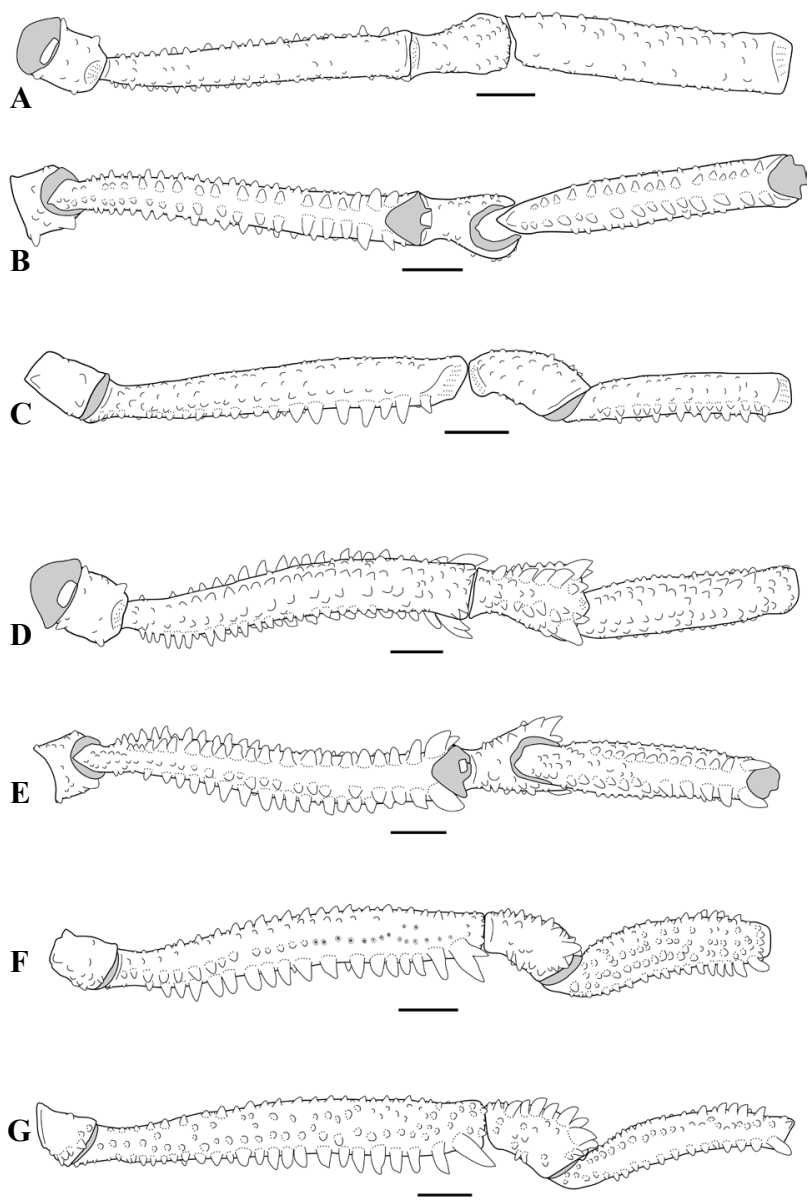

Figure 5. Legs III-IV of Rhaucus papilionaceus rest. comb. (ICN-AO-1162), male. Leg III: A. Dorsal view. B. Ventral view. C. Retrolateral view. Leg IV: D. Dorsal view. E. Ventral view. F. Retrolateral view. G. Prolateral view. Scale bars $=1 \mathrm{~mm}$.
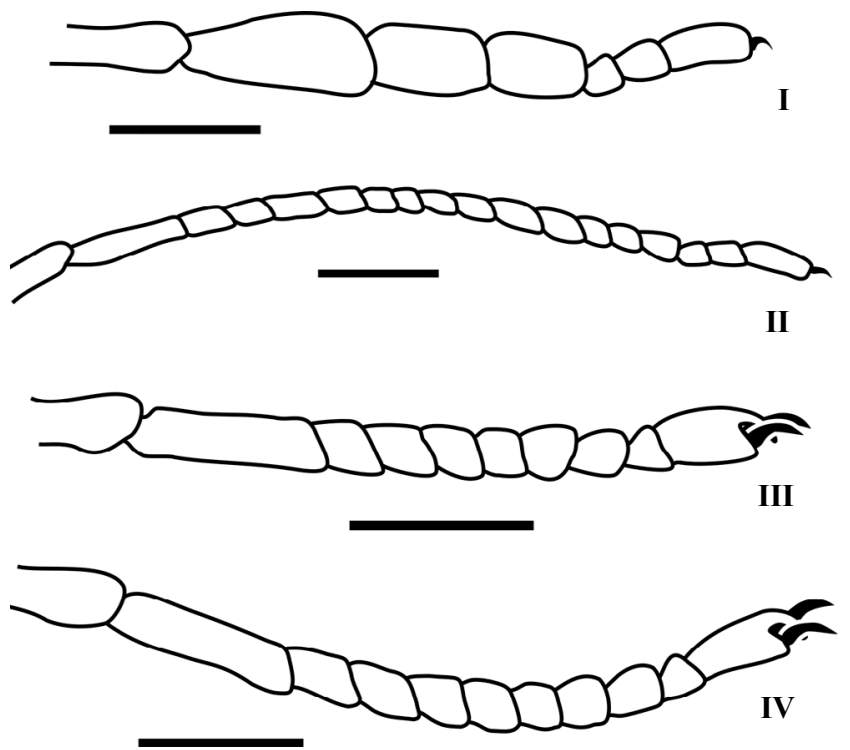

Figure 6. Tarsomeres I-IV of Rhaucus papilionaceus rest. comb. (ICN-AO-1162), male. Scale bars $=1 \mathrm{~mm}$.
-73.025316], 5.xi.2013, C. Perafán \& D. Martínez leg.; (ICN-AO-1374) $1 \delta^{\Uparrow} 19$ from Suaita, Bosque Fundación San Cipriano, 6 ${ }^{\circ} 10^{\prime} 24^{\prime \prime} \mathrm{N} ; 7^{\circ} 25^{\prime} 36,4^{\prime \prime} \mathrm{W}, 2 . v .2013,1708 \mathrm{~m}$, Andean forest, Catalina Romero \& German Amat leg.; (ICNAO-1381) $1 \overbrace{}^{\Uparrow}$ from Zapatoca, vereda La Cacica, Reserva La Montaña Mágica, $6^{\circ} 50.310 \mathrm{~N} ; 73^{\circ} 17.685 \mathrm{~W}, 7 . x i .2013,1740$ m, Carlos Perafán \& Daniela Martínez leg.; (ICN-AO-1725) $1 \widehat{\jmath}$ from Suaita, San José de Suaita, Bosque Fundación San Cipriano, 1-8.vii.2014, 1780 m, Catalina Romero \& Daniela Martínez leg.

Etymology. Eugène Simon did not explain the etymology of the species names in his works (A.B. Kury, pers. comm.). We deduced that the specific epithet comes from the Latin word papilio (= butterfly), referring to the shape of the paired blots on the dorsal scutum of the species, which resemble a butterfly with open wings (Figure 1).

Redescription. Male (ICN-AO-1162). Measurements: $\mathrm{CL}=2.1 \mathrm{CW}=3.8, \mathrm{AL}=2.6, \mathrm{AW}=5, \mathrm{BaCh}=1, \mathrm{Fe} \mathrm{III}=5.2, \mathrm{Fe}$ $\mathrm{IV}=7.3$, Ti III= 3.2, Ti IV=4. Intraspecific variations of body and appendages measurements $(\mathrm{n}=10, \min -\max ): \mathrm{CL}=2$ 2.3, $\mathrm{CW}=3.3-4.1, \mathrm{AL}=2.3-3, \mathrm{AW}=4.3-5, \mathrm{BaCh}=0.8-1.1$, Fe III=5.1-6.3, Fe IV=7-8.8, Ti III=3-3.8, Ti IV=4-5.

Dorsum. Dorsal scutum alpha type, mostly smooth (Figures 2A, 3A), with a pair of oblique triangular yellow blots on DS (Figure 2A, 3A-B). Abdominal scutum widest at groove II; areas I-IV slightly granulate. Carapace with a few granules on the anterolateral region (Figure 3A). Ocularium low without median depression, armed with a cluster of granules (Figures 3A, C). Lateral margins of DS with a few lateral pegs on the medial region (Figure 3A). Mesotergum faintly delimited and divided in four areas: Area I with a pair of medium-sized paramedian tubercles; area II and IV with few minute granules, and area III with a pair of paramedian conical, medium-sized tubercles (Figures 2D-E, 3A, C). Posterior border of scutum slightly curved and with a row of tubercles. Free tergites I-III with a row of granules (Figures 3A).

Venter. Stigmatic area with a few granules. Large, oval, and transverse stigmata. Coxa I with two parallel rows of tubercles increasing in size distally and with an anterior smooth space for the pedipalps to rest (Figure 2C); coxa II longer than coxa I, slightly granulate; coxa III longer than I and II, granulate, with posterior margin curved; coxa IV strongly backward, granulate (Figures 2C, 3C). Genital operculum slightly granulate.

Chelicera. Chelicera swollen. Basichelicerite rectangular, with dispersed granules, one group of tubercles of different sizes on the proximal border, one small and one large ectal sub-distal tubercle; one medium-sized, meso-distal tubercle and one proximal medium-sized tubercle (Figure 4A). Ventrally, there is a group of five small tubercles and, in mesal view, a big irregular tubercle on the distal portion, three in the medial portion and one little proximal tubercle are evident (Figures 4A-B). Hand with one tubercle near the joint of the movable finger. Fixed finger with the inner 

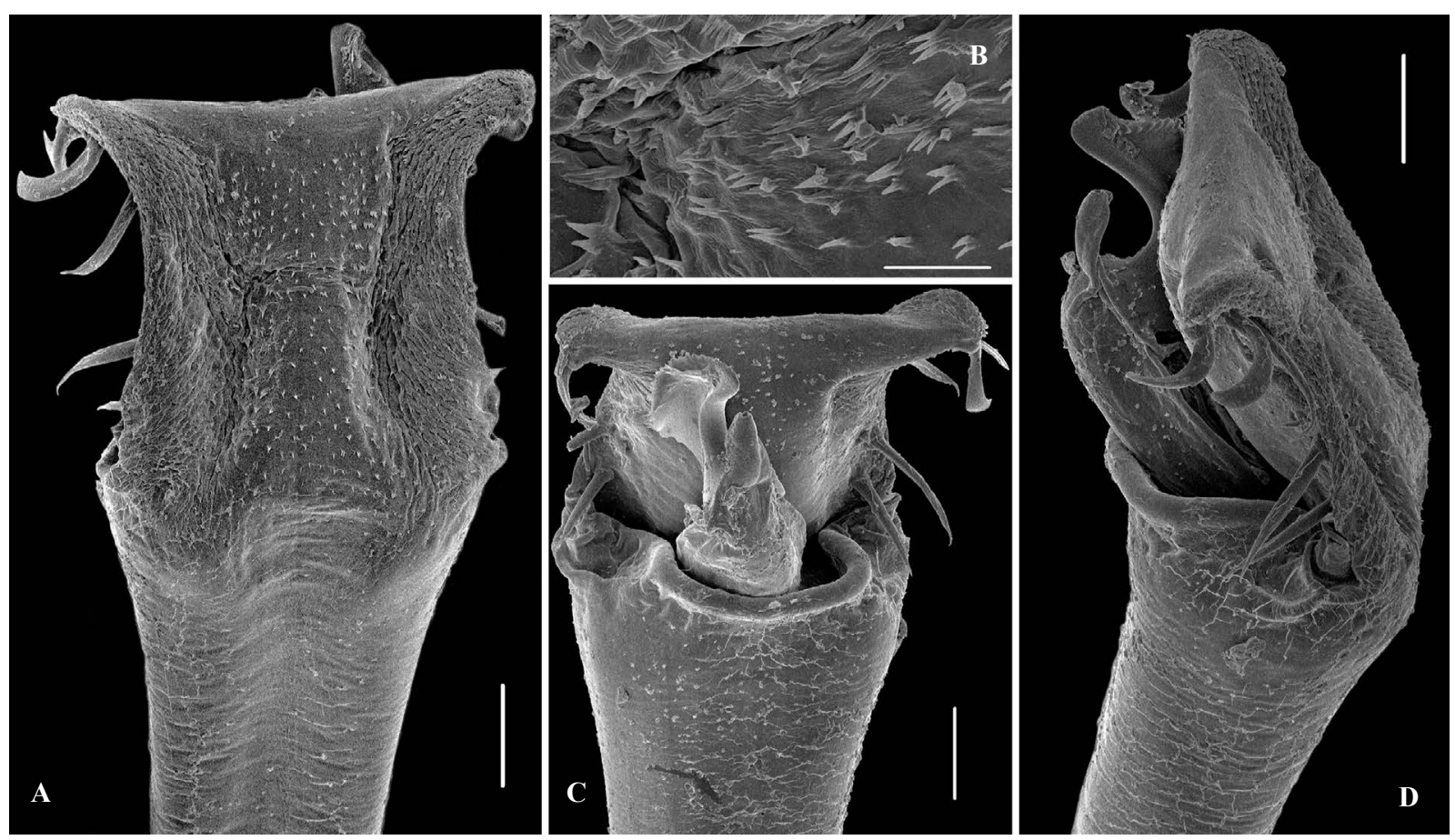

Figure 7. Distal portion of male genitalia of Rhaucus papilionaceus rest. comb. (ICN-AO-1162). A. Ventral view. B. Detail of type 4 microsetae of ventral plate. C. Dorsoapical view. D. Lateroapical view. Scale bars: A, C-D = $50 \mu \mathrm{m}, \mathrm{B}=10 \mu \mathrm{m}$.

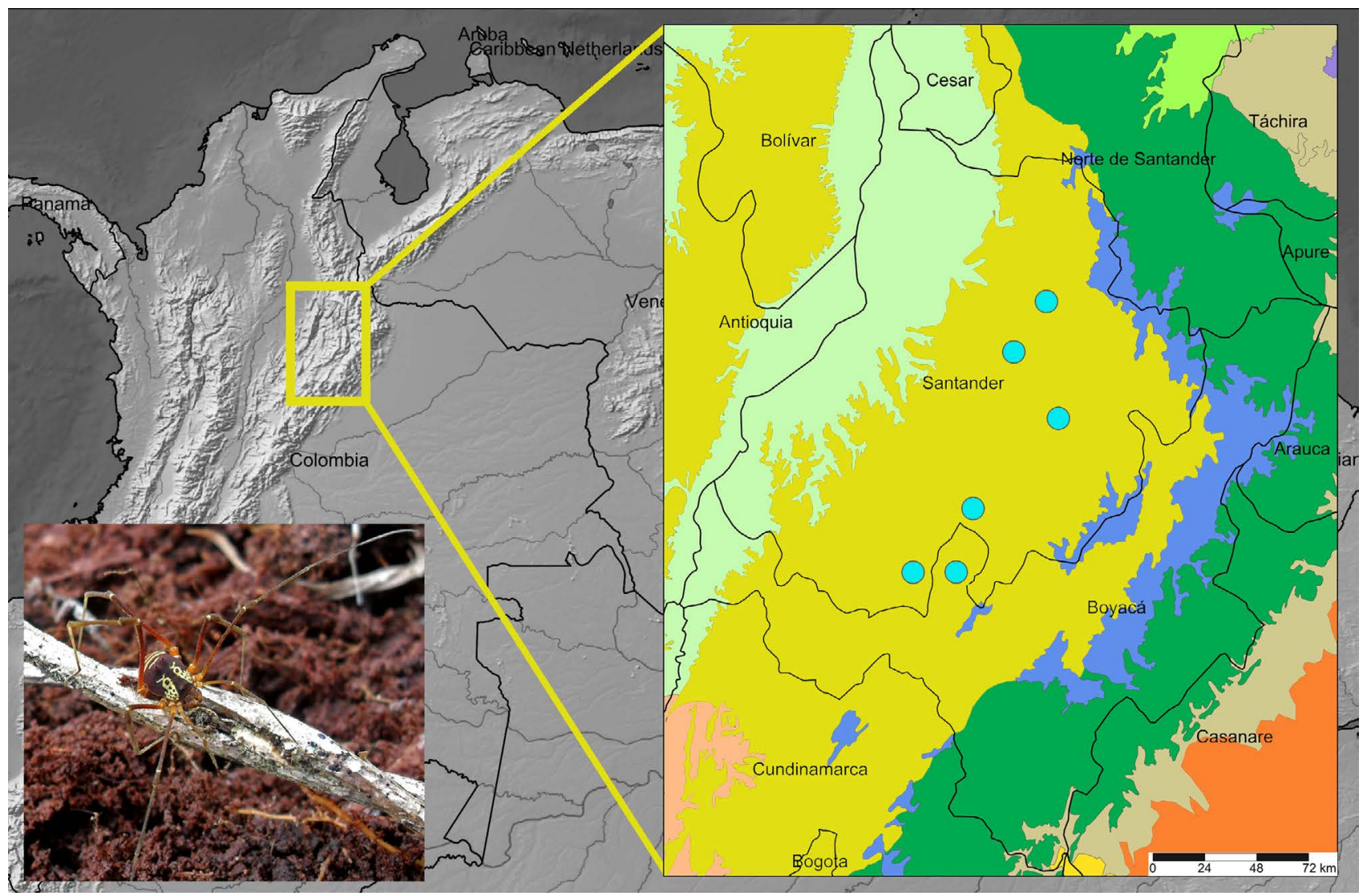

Figure 8. Map showing the distribution of Rhaucus papilionaceus rest. comb. (blue circles) in Colombia. The yellow area corresponds to the Magdalena Valley montane forest ecoregion (NT0136). 
surface finely grooved. Movable finger with one conical, sub-basal tooth and with the inner surface at distal portion dentate (Figure 4C).

Pedipalpus. Coxa with one meso-distal granule dorsally and ventrally. Trochanter with one dorsal short tubercle and one big ventro-distal tubercle. Femur compressed laterally, with a dorsal row of aligned triangular setiferous tubercles of different sizes -not reaching the distal portion-, ventrally with three basal, small setiferous tubercles, seven individual conical large setiferous tubercles at median portion, and three small tubercles on the distal portion (Figure 4D-E). Patella distally depressed, with minute dorsal granules. Tibia spoon-shaped, dorsally granulate, with lateral borders slightly tuberculate and some spiniferous tubercles on distal portion (Figure 4D); inner surface slightly striated. Tarsus long, conical, with some dorsal granules and ventrally with two rows of thickened setae (Figure 4F).

Legs. Coxa I-III dorsally and ventrally with some granules; coxa IV coarsely granulate, with an anterolateral clavi inguines and with a posterolateral multicapitate apophysis (Figure 2C). Trochanter I-II dorsally and ventrally with some minute granules; III-IV with some dorsal and ventral tubercles (Figures 5A-B, D-E); IV with a group of tubercles visible in retrolateral view and one prolateral row of tubercles beginning at the ventral face of the trochanter and ending in the dorsal face (Figures 5F-G). Femora I-II sub-straight; femora III-IV sigmoid, granulated, ventrally with two longitudinal rows of tubercles along the entire length. Femora III-IV with one prolateral and one retrolateral row of tubercles increasing in size distally (in Fe IV the distal-most tubercle of the retrolateral row is bifid and thicker than the others while the distal-most tubercle of the prolateral row is conical) (Figures 5B-C, E-G). Patellae I-IV dorsally granulated, curved; Pa IV with a prolateral row of prominent conical tubercles and with two median tubercles on the retrolateral-ventral side (Figures 5D-G). Tibiae I-IV granulated; tibiae III-IV ventrally with two longitudinal rows of tubercles along the entire length (in Ti IV increasing in size distally) (Figures 5B, E). Metatarsi I-IV with one ventrodistal setae. Tarsi of legs I-II with one smooth claw; tarsi of legs III-IV with two subparallel smooth claws and tarsal process (Figure 6). Tarsal counts: 6(3)-6(3)/18(3)18(3)/10-10/12-11. Intraspecific variation of tarsomeres $(\mathrm{n}=10$, min-max): Leg I = all with 6; Leg II = 13(3)-18(3); Leg III = 9-10; Leg IV = 10-12.

Color (in ethanol). Carapace strong brown (55), reticulated at laterals of the ocularium. Blots in carapace brilliant yellow (83). Chelicerae and coxae I-IV strong brown (55). Pedipalpus and trochanters I-IV strong yellow (84). Legs I-IV strong brown (55).

Penis. VP of penis subrectangular with slightly concave distal border (Figure 7A) and two lateral, elongated, dense patches of type 4 microsetae (Figure 7B). VP with two apical MS C curved and laterally inserted; two MS D, the most distal, large and straight one following the same lateral row as MS C, and the other one, smaller, inserted dorso-laterally on the third portion of the VP; two MS A straight and laterally inserted, near to D2 (Figures 7C); two small MS E volcanoshaped in the ventral face; one small MS B volcano-shaped inserted laterally in the base of the VP (Figure 7D). Glans mostly smooth; stylus long, wattle barbels, short finger-like process rounded, enlarged (Figure 7D).

Female. Similar to male, but differs by having anterior part of carapace narrower and coda divergent, ocularium lower, abdominal scutum more strongly convex, free tergites and posterior area of scutum wider, tubercles of area III shorter, legs III-IV and associated rows of tubercles thinner, and chelicerae not hyperthelic.

Diagnosis. A pair of oblique yellow blots on DS (transverse lines in $R$. florezi, R. quinquelineatus and $R$. vulneratus, reticulate pattern in $R$. robustus and $R$. serripes), beginning at ozopores level and extending to area II of carapace (Figures 2A, 3A-B). Distal-most tubercle on retrolateral face of femur IV bifid bigger than the others (Figure 5F) (minuscule tubercle in R. vulneratus, of the same size as the others in $R$. quinquelineatus, median and not forked in $R$. florezi and $R$. robustus, two tubercles close together in $R$. serripes). Patella IV with a prolateral row of robust tubercles (Figure $5 \mathrm{G}$ ), which is absent in the remaining species of Rhaucus.

Distribution. Colombia, Santander department: Puente Nacional, San Gil, Suaita and Zapatoca municipalities, between 1550 and 1740 m. a. s. 1, in the Magdalena Valley montane forests ecoregion (Figure 8).

\section{Discussion}

In general, Rhaucus exhibits a high level of endemicity, distributing in the mountains of central Andes of Colombia restricted to Cundinamarca, Boyacá and Santander departments (García \& Kury, 2017). Rhaucus papilionaceus rest. comb. shows that condition, and has been recorded in montane forests of Santander and Boyacá departments between 1500 to 1780 m.a.s.l. In fact, there were no specimens found from Bogotá (as stated in the original label), which is located at 2600 m.a.s.l., so, we think that the original label could be wrong.

On the other hand, a particularity of this species is that it occurs in lowest montane forests, almost a thousand meters below the other species of Rhaucus (2300 to 3600 m.a.s.l.) (García \& Kury, 2017). We can now conclude that the genus may be found in montane forests and páramos (Andean highlands) of Colombia, from 1500 to 3600 m.a.s.l. in the Magdalena Valley montane forests (NT0136), the Cordillera Oriental montane forests (NT0118) and the Northern Andean páramo (NT1006) ecoregions.

Finally, the examination of type material and the comparison with freshly collected material and/or photographs are two of the main tools to detect described and new species of harvestmen. In this case, photographs of the holotype of E. papilionaceus, together with a photograph 
of a living specimen in a field guide of harvestmen and millipedes from La Meseta Natural Reserve (Suaita, Santander department) (Martínez-Torres, et al., 2016) allowed us to confirm the identity of the species, and posteriorly review the vouchers deposited in ICN and MNRJ.

\section{Acknowledgments}

We are thankful to Eduardo Flórez (ICN-UNAL) for the loan of Rhaucus material. Adriano Kury (MNRJ) facilitated the laboratory work and made important comments about Simon's works. Ricardo Pinto-da-Rocha (USP) kindly shared us photographs of the holotype of Erginus papilionaceus from MNHN (Muséum National d'Histoire Naturelle, Paris, France). Daniela Martínez (ICN-UNAL) kindly shared us the photograph of the living specimen in figure 8. The SEM micrographs were taken in the Center for Scanning Electron Microscopy (MNRJ) with the support of Beatriz Cordeiro. The OmniPaper Project (http://www.museunacional.ufrj.br/mndi/Aracnologia/ pdfliteratura/pdfs\%20opiliones.htm) created by Adriano Kury was very helpful providing access to some papers. Finally, we thank the three referees of this manuscript for their recommendations. This study has been supported by a scholarship from the Coordenação de aperfeiçoamento de pessoal de nivel superior (CAPES) to AFG.

\section{Contribution of the authors}

A. F. García: Introduction, illustrations, photographs, redescription, discussion. D. Ahumada-C.: Redescription.

\section{Conflicts of interest}

The authors declare that they have no competing interests.

\section{References}

García, A.F., Kury, A.B. (2017). Taxonomic revision of the Andean harvestman genus Rhaucus Simon, 1879 (Arachnida, Opiliones, Cosmetidae). Zootaxa. 4338 (3): 401-440. https:// doi.org/10.11646/zootaxa.4338.3.1

Hadley, A. (2015). CombineZP. Image stacking software. Accessed in June 2017. Available from http://www.hadleyweb.pwp. blueyonder.co.uk/CZP/Installation.htm

Henriksen, K.L. (1932). Descriptiones Laniatorum (Arachnidorum Opilionum Subordinis) fecit William Sørensen. Opus posthumum recognovit et edidit Kai L. Henriksen. Det Kongelige Danske Videnskabernes Selskabs skrifter [ = Mémoires de l'Académie Royale des Sciences et des Lettres de Danemark], København [Copenhague], Naturvidenskabelig og Mathematisk Afdeling [= Section des sciences Naturelles et mathématiques], sér. 9; 3 (4): 197-422.
Jaffer, A. (2001). NBS/ISCC Centroids. Color-Name Dictionaries. Accessed in September 2017. Available from http://people. csail.mit.edu/jaffer/Color/Dictionaries\#nbs-iscc

Kury, A.B. (2003). Annotated catalogue of the Laniatores of the New World (Arachnida, Opiliones). Revista Ibérica de Aracnología. 1: 1-337.

Kury, A.B. (2012). A new genus of Cranaidae from Ecuador (Opiliones: Laniatores). Zootaxa. 3314: 31-44.

Kury, A.B. \& Ferreira, C.P. (2012). Two new species of Roquettea Mello-Leitão, 1931 from northern Brazil (Opiliones: Laniatores: Cosmetidae). Zootaxa. 3328: 35-46.

Kury, A.B. (2013). Order Opiliones Sundevall, 1833. In: Zhang, Z.Q. (Ed.), Animal Biodiversity: An Outline of Higherlevel Classification and Survey of Taxonomic Richness (Addenda 2013). Zootaxa. 3703 (1): 27-33. https://doi. org/10.11646/zootaxa.3703.1.7

Kury, A.B. \& Barros, C.M. (2014). A new genus and eight new species of Amazonian cosmetines (Opiliones, Laniatores, Cosmetidae). Zoological Studies. 53: 1-46.

Kury, A.B. \& Villarreal, M.O. (2015). The prickly blade mapped: Establishing homologies and a chaetotaxy for macrosetae of penis ventral plate in Gonyleptoidea (Arachnida, Opiliones, Laniatores). Zoological Journal of the Linnean Society. 174 (1): $1-46$.

Kury, A.B. (2016). A classification of the penial microsetae of Gonyleptoidea (Opiliones, Laniatores). Zootaxa. 4179 (1): 144-150.

Kury, A.B. \& García, A.F. (2016). On the identity of Flirtea (Arachnida, Opiliones, Cosmetidae). Zootaxa. 4093 (2): 231-247.

Kury, A.B. \& Medrano, M. (2016). Review of terminology for the outline of dorsal scutum in Laniatores (Arachnida, Opiliones). Zootaxa. 4097: 130-134. http://dx.doi.org/10. 11646/zootaxa.4097.1.9

Martínez-Torres, D., Romero-Ortiz, C., Flórez, E. (2016). Los arácnidos y miriápodos del bosque La Meseta (Suaita, Santander). Serie Miniguías de Campo del Instituto de Ciencias Naturales. $N^{\circ} 27$

Medrano, M. \& Kury, A.B. (2016). Characterization of Platymessa with redescription of the type species and a new generic synonymy (Arachnida, Opiliones, Cosmetidae). Zootaxa. 4085 (1): 52-62.

Olson, D.M., Dinerstein, E., Wikramanayake, E.D., Burgess, N.D., Powell, G.V.N., Underwood, E.C., D’amico, J.A., Itoua, I., Strand, H.E., Morrison, J.C., Loucks, C.J., Allnutt, T.F., Ricketts, T.H., Kura, Y., Lamoreux, J.F., Wettengel, W.W., Hedao, P., Kassem, K.R. (2001). Terrestrial ecoregions of the world: a new map of life on earth. BioSci. 51: 933-938.

Shorthouse, D.P. (2010). SimpleMappr, an online tool to produce publication-quality point maps. Accessed in September 2017. Available from http://www.simplemappr.net 